\title{
Low Lignin Mutants and Reduction of Lignin Content in Grasses for Increased Utilisation of Lignocellulose
}

\author{
Cecilie S. L. Christensen 1 and Søren K. Rasmussen * (10) \\ Department of Plant and Environmental Sciences, University of Copenhagen, DK-1871 Frederiksberg C, \\ Denmark; cslc@plen.ku.dk \\ * Correspondence: skr@plen.ku.dk; Tel.: +45-353-334-36
}

Received: 20 March 2019; Accepted: 17 May 2019; Published: 21 May 2019

check for updates

\begin{abstract}
Biomass rich in lignocellulose from grasses is a major source for biofuel production and animal feed. However, the presence of lignin in cell walls limits its efficient utilisation such as in its bioconversion to biofuel. Reduction of the lignin content or alteration of its structure in crop plants have been pursued, either by regulating genes encoding enzymes in the lignin biosynthetic pathway using biotechnological techniques or by breeding naturally-occurring low lignin mutant lines. The aim of this review is to provide a summary of these studies, focusing on lignin (monolignol) biosynthesis and composition in grasses and, where possible, the impact on recalcitrance to bioconversion. An overview of transgenic crops of the grass family with regulated gene expression in lignin biosynthesis is presented, including the effect on lignin content and changes in the ratio of $p$-hydroxyphenyl $(\mathrm{H})$, guaiacyl $(\mathrm{G})$ and syringyl (S) units. Furthermore, a survey is provided of low-lignin mutants in grasses, including cereals in particular, summarising their origin and phenotypic traits together with genetics and the molecular function of the various genes identified.
\end{abstract}

Keywords: brown midrib; cell wall; gold hull and internode; grass family; lignin; monolignol pathway; mutational breeding; orange lemma; transgenic cereals

\section{Introduction}

Cereals are a basic food supply for humans and animals worldwide and include rice, maize, wheat, barley and sorghum. They are mainly grown for their nutritional grains that provide dietary calories for human consumption, animal feed and alcoholic beverages. However, whole-crop silage is also a major product in agriculture and is used for animal fodder. Straw from grain production is often considered a by-product, but it is still essential for animal bedding and feed or can be returned to the soil to maintain soil fertility. Additionally, cereals are used in bioindustries for the production of biofuel, textiles, paper, and biochemicals (for a detailed list see [1,2]). The worldwide demand for cereals is growing, but a decrease in their production is starting to be seen [3]. It is therefore crucial to understand the barriers to efficient utility and breeding for new varieties with improved (utility) benefit as feedstuff for animals and bioproducts. In particular, the concept of the multi-purpose crop, in which the grains are used for food and feed and the straw for bioenergy seeks to overcome the food-feed-fuel dilemma by improving the ligno-cellulosic material from straw in second-generation bioethanol production [4].

Lignocellulose is the main component of plant cell walls and the most abundant organic material on earth. It is primarily composed of energy-rich polysaccharides in the form of cellulose, hemicellulose and pectin, rigid phenolic polymers forming lignin and structural (glyco) proteins. The structure is vital for plant growth and serves as a scaffold providing structural and mechanical strength to the plant and protection against external stresses; it encloses each cell individually and facilitates water and solute 
flux in the vascular systems $[5,6]$. Besides these properties, lignocellulose is also an essential source of animal feed and used in various bioindustries [2].

The composition of the lignocellulosic material differs depending on the biomass source, but it usually consists of $20-50 \%$ cellulose, $20-30 \%$ hemicellulose, $7-30 \%$ lignin and $5-35 \%$ pectin, with lower amounts of structural proteins that all depend on the plant species, as reviewed by $[5,7,8]$. Plant cells are made up by two types of cell walls, i.e., primary cell walls (PCW) and secondary cell walls (SCW) placed between the middle lamella and the plasma membrane (Figure 1). PCWs surround all plant cells and are continuously formed during cell growth. The structure is thin and flexible, suitable for elongating cells, but still sufficiently strong to withstand arising turgor pressure [9,10]. It consists primarily of cellulose and hemicellulose, with higher amounts of pectin and proteins in dicots compared to monocots $[5,11]$. SCWs are formed between the PCW and the plasma membrane in specialised cells such as sclerenchyma and xylem vessels after cell elongation has been completed. They are composed of a greater amount of cellulose and hemicellulose than PCW, and pectin is also partly replaced by lignin. These components form a thicker cross-linked matrix than in PCWs. As mentioned above, the function of lignocellulose is to provide mechanical strength to the cells and to facilitate fluid transport. Lignin is the fundamental component for forming that scaffolding structure and its occurrence has also been documented in PCW and the middle lamella $[5,6]$.

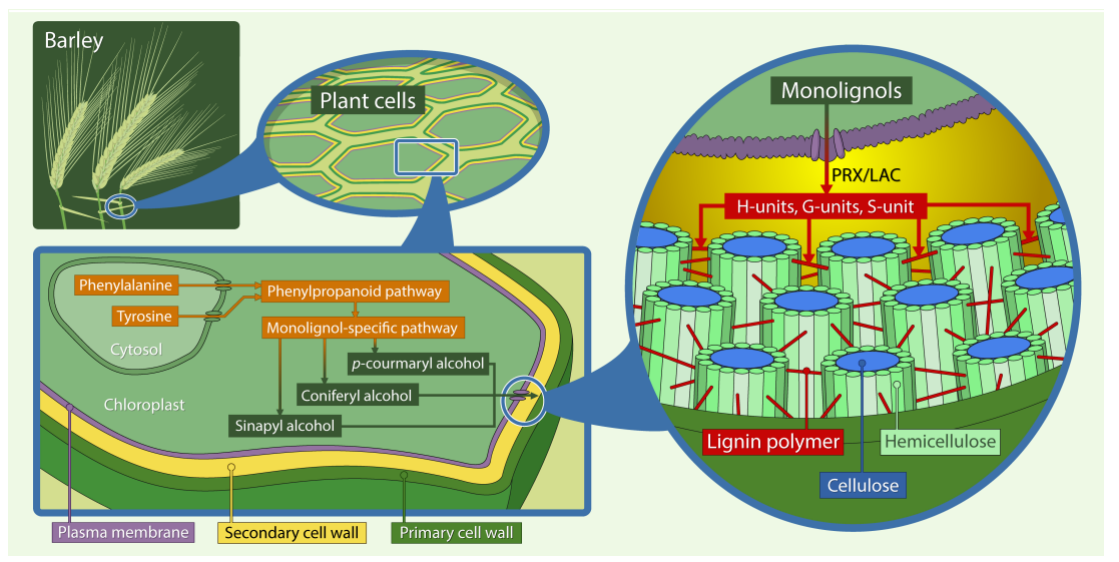

Figure 1. Schematic illustration of the lignocellulosic matrix in the secondary cell wall of the grass family. The main polymers shown are cellulose, hemicellulose, and lignin (shown simplified and not to scale: for microscopic pictures see [12]). They are organised in structures called microfibrils that give structural stability to the plant cell wall. Lignin is the component providing the recalcitrant structure embedding cellulose together with hemicellulose. Lignin is mainly composed of p-hydroxyphenyl $(\mathrm{H})$, guaiacyl (G) and syringyl (S) units, which are derived from 4-hydroxycinnamyl alcohols also known as monolignol, p-coumaryl alcohol, coniferyl alcohol and sinapyl alcohol. The monolignols are synthesised in the cytosol from phenylalanine and tyrosine (grasses only) through the phenylpropanoid pathway and monolignol-specific pathway, then exported across the plasma membranes into the secondary cell wall and oxidized by cell wall-bound peroxidase (PRX) and laccase (LAC), before polymerization into the lignin polymer. (Illustration: Martin Mook).

The recalcitrant structure of lignin is the major limitation of utilising SCWs' nutritional polysaccharides for animal feedstock and producing bioproducts. Lignin also serves as a mechanical defence barrier and is known to accumulate under pathogenic attacks [13-15]. It has also been demonstrated that genes in the monolignol pathway are directly affected by fungal infection [16-18]. For those reasons, lignin biosynthesis has received significant attention, making it one of the most studied pathways [19]. The expression of genes in the pathway has been modified in order to decrease lignin or alter its composition, thus making the pathway a perfect target for precise genome editing [19]. The involvement of transcription factors in lignin biosynthesis has recently been reviewed [20] and will not be discussed further here. Furthermore, both naturally spontaneous and chemically-induced 
mutants have been identified and commercialised for animal fodder, showing increased efficiencies for digestion, and are therefore used in breeding programmes. However, in terms of decreasing lignin recalcitrance to bioconversion, there is often a risk of disease infections and dwarfing, depending on the gene being modified [21]. Promising target genes for reduction of lignin recalcitrance without compromising biomass, yield and quality are final genes in the pathway such as $C A D$ encoding cinnamyl alcohol dehydrogenase and COMT encoding caffeic acid $O$-methyltransferase [22,23]. CAD is responsible for reducing cinnamaldehydes to cinnamyl alcohols, the precursors of the building blocks of lignin, also known as monolignols, whereas COMT is a multifunctional enzyme, but with a preference for methylations of 5-hydroxyconiferaldehyde to sinapaldehydes and therefore primarily affecting the synthesis of syringyl monolignol $[24,25]$ The genes responsible for the brown midrib phenotype in (bm1, bm3) maize and (bmr6, bmr12) sorghum, which are known for reduced lignin, have mutations within the $C A D$ and $C O M T$ genes affecting their expression. These naturally-occurring low-lignin mutants are of interest for academia and the fodder industry as an alternative source for animal feed and bioproducts [26]. Promoting these well-described varieties avoids the issue of transgenic regulation in Europe, thus increasing the marketing area and also including the organic market. Therefore, downregulating these genes will resemble the naturally-occurring mutants with reduced lignin identified in several cereal crops in the early 20th century.

This review focuses on lignin reduction in important cereals for animal feed (and bioproducts), with a particular focus on papers published after 2010 and updating an earlier review paper, but still including references to primary papers. The aim is (1) to present the monolignol biosynthetic pathway, (2) to provide an overview of recent biotechnology/bioengineering studies targeting genes in the phenylpropanoid and monolignol-specific pathway, and (3) to introduce natural low-lignin mutants with regards to occurrence and phenotypic studies.

\section{Lignin Biosynthetic Pathway and Composition in Grasses}

Lignin is a phenolic polymer of three units: p-hydroxyphenyl $(\mathrm{H})$, guaiacyl $(\mathrm{G})$ and syringyl (S), which are derivatives of hydroxycinnamyl alcohol, also called monolignols, $p$-coumaryl alcohol, coniferyl alcohol and sinapyl alcohol, respectively. They only differ in the degree of methylation. The monolignols are synthesised from phenylalanine or tyrosine (exclusively for grasses) $[27,28]$ through the general phenylpropanoid pathway, which is the precursor for numerous specialised metabolites, including flavonoids, tannins and coumarins, and monolignol-specific pathways in the cytosol, before polymerisation in the cell wall. The steps involved in the synthesis are well documented $[29,30]$. Briefly, phenylalanine and tyrosine are products of the shikimate pathway synthesised in the chloroplasts and exported to the cytosol, where the monolignols are synthesised via a series of enzymatic reactions, illustrated in Figure 2. Deposition of monolignols from the cytosol to the secondary cell wall is unclear, and it is being debated whether they are exported through passive diffusion or actively transported [31]. However, the monolignol-specific pathway is very plastic with numerous inter-specific variations and co-regulated genes. This is explicit with the complex constellation of the lignin polymer, varying in composition between plants and even between cell types. Lignin of grasses primarily consists of S- and G-units. Additionally, grasses also contain H-units and significantly larger amounts of ferulic acid (FA) and $p$-coumaric acid ( $p$ CA) $[11,32]$. The FA and $p$ CA cross-link to the lignocellulosic matrix, providing structural integrity of the cell wall. They form covalent linkages or ether bonds between polysaccharide and lignin components [33]. Furthermore tricin, a member of the flavonoid family, has recently been discovered in the lignin polymer and designated an initiator of lignin chains [34,35]. Tricin is also thought to be found almost exclusively in grasses, with a little amount in other monocots and a few traces in alfalfa [36]. Importantly, the composition of the lignin polymer is relevant in terms of recalcitrance to bioconversion after the lignocellulosic material has undergone thermochemical pretreatment followed by enzymatic or acid/alkaline hydrolysis. The monolignols are coupled with recalcitrant C-C and C-O-C (ether) bonds, providing their recalcitrant structure. However, the coupling of monomers differs: $\mathrm{H}$ - and 
G-units can couple via $\beta-5$ (from monomer-monomer and monomer-oligomer reactions) and 5-5 (from oligomer-oligomer reactions) coupling modes with C-C linkages, whereas S-units are linked with $\beta-O-4$ which are more easily degraded [37]. A ratio between the monolignols ( $\mathrm{S} / \mathrm{G}$ ratio) is often used as a validation factor to draw conclusions about cell wall degradation ability. Shortly, a high ratio (above 1.0) indicates more S-units than G-units and a low ratio (below 1.0) indicates less S-unit than G-units. It is often stated that a high ratio favours digestibility, and the reason for that is discussed. One hypothesis is that more S-units compared to G-units increases the number of labile $\beta-O-4$ bonds and thereby affects enzymatic digestibility positively. On the contrary, increased S-units lead to a more linear structure with uncondensed (high $\beta-O-4^{\prime}$ ) lignin, which provides higher coverage and interaction with the cellulose fibres and thereby lower enzymatic digestibility. Therefore, using the $S / G$ ratio as a validation factor only partially contributes to biomass recalcitrance. Furthermore, $p C A$ linkage with S-units via the ether bond and $p C A$ is thought to inhibit fermentation due to toxic effect on yeast $[38,39]$. Similarly, changes in FA compounds using the monolignol ferulate transferase (FMT) gene also affect recalcitrance by introducing more easily broken ester bonds [40,41]. Lignin composition and content can be changed with regards to saccharification by regulating genes in the monolignol-specific pathway without compensating for biomass. Therefore lignin has been a target for genetic manipulation for several decades and remains of interest today.

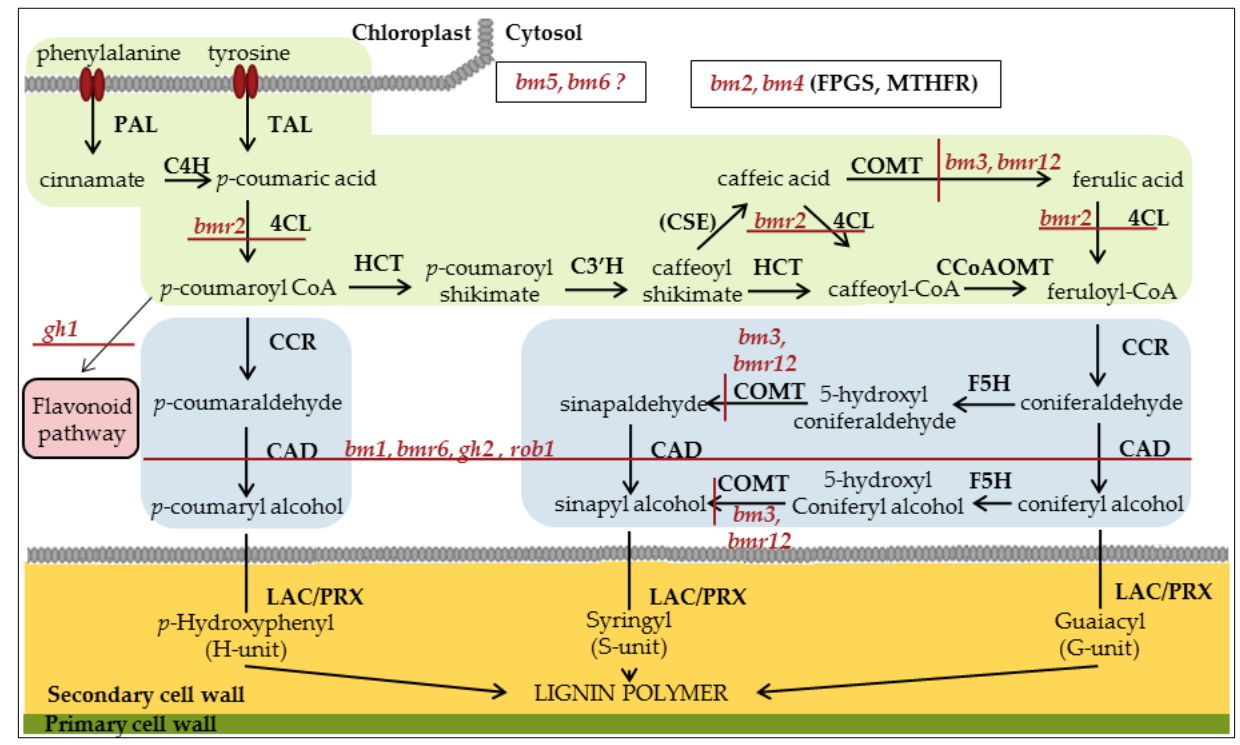

Figure 2. Monolignol biosynthetic pathway for grasses based on studies on Brachypodium distachyon [30,32] which is regarded model plant for grasses. The illustration was inspired by [42]. The green box represents the general phenylpropanoid pathway, the blue boxes represent the monolignol-specific pathway, and the light red box indicates $p$-coumarate-CoA as the precursor for the flavonoid pathway. Monolignols $p$-coumaryl alcohol, coniferyl alcohol, and sinapyl alcohol are synthesised in the cytosol and exported to the secondary cell wall where they undergo oxidation by cell wall-bound peroxidase (PRX) and laccase (LAC) prior to radical coupling in the lignin polymer. Red italic abbreviations for mutants: brown midrib maize (bm), brown midrib sorghum (bmr), orange lemma barley (rob) and gold hull and internode rice ( $g h$ ), with identified mutations impairing respective gene enzyme activity indicated by red lines. Enzyme abbreviations: phenylalanine ammonia-lyase (PAL), tyrosine ammonia-lyase (TAL), cinnamate 4-hydroxylase (C4H), 4-coumarate coenzyme A ligase (4CL), $p$-hydroxycinnamoyl-CoA:quinate/shikimate hydroxycinnamoyl transferase (HCT), p-coumarate 3-hydroxylase (C3'H), caffeoyl shikimate esterase (CSE), caffeoyl-CoA O-methyltransferase (CCoAOMT), cinnamoyl CoA reductase (CCR), ferulate 5-hydroxylase (F5H), caffeic acid/5-hydroxyferulic acid O-methyltransferase (COMT) and cinnamyl alcohol dehydrogenase (CAD). Folylpolyglutamate synthase (FPGS) and methylenetetrahydrofolate reductase (MTHFR) are not structural genes in the phenylpropanoid pathway. 


\section{Biotechnology and Bioengineering of Monolignol Pathway in Grasses}

The economic advantages of increasing cereals' nutritional value and replacing fossil fuels with biofuels have driven scientists to investigate and regulate nine of the genes in the monolignol biosynthetic pathway (Table 1), making it an intensively studied pathway. Furthermore, the visual red/orange colouration appearing in stems after downregulating certain genes also makes it attractive as an easy target for new bioengineering methods. The most-used method for regulation and study of the function of genes is "downregulating expression" (of genes) using RNA interference (RNAi). This method introduces small regulatory RNAs (siRNA and miRNA) to the cell, which bind with the RNA-induced silencing complex, Argonaute and other effector proteins, that destroy messenger RNA (mRNA) and thereby prevent the formation of proteins [43]. However, the genes still function and the expression/formation of proteins varies greatly. Repression can be lost completely over a few generations. Furthermore, repression of gene expression does not give a complete picture of the function of a gene, although, it is still a very widely used method. In contrast, using CRISPR/Cas9 to directly knock out gene function by creating stable indel mutations is a more advantageous way of studying gene function [44]. However, in contrast to chemically-induced mutations, CRISPR/Cas9 site-directed mutagenesis requires that the nucleotide sequence of the candidate gene is known before the precise indel mutation can be designed, with stable inheritance over a few generations. This is a relatively new method that has only been used in the most recent studies. However, in July 2018 the EU officially declared that mutations created by CRISPR/Cas9 technology, in contrast to induced mutations, are not exempt from the GMO regulation [45].

It is mostly lignin biosynthetic genes in maize (8) and switchgrass (7) that have been studied by a transgenic approach, with a few in rice (4), Brachypodium (4) and barley (1) (Table 1). Generally, downregulating or knocking out genes leads to a reduced lignin content. However, the estimates of lignin concentration vary greatly depending on the method used for extraction. The most commonly used methods are the gravimetrically determined Klason lignin and the spectrophotometric acetyl bromide lignin method. Briefly, Klason lignin measures insoluble lignin after sulfuric acid hydrolysis of cell walls [46], whereas acetyl bromide lignin is based on the solubility of lignin and measures phenolic compounds' UV absorbance at $280 \mathrm{~nm}$ [47]. Large studies have examined and compared quantification methods of lignin and concluded that Klason lignin estimates higher concentrations than acetyl bromide lignin, although both methods are widely used $[48,49]$.

Modifying PAL, $4 C L$ and $C 3 H$ gene expression tends to affect plant growth negatively and induce sterility. However, downregulating genes later in the pathway (F5H, CCOAMT, CCR, COMT, and CAD) does not have any negative effect on growth (Table 1). This is in contrast with what has been reported for bm3 mutants, which have mutations in the COMT gene [21]. It can be explained by RNAi only reducing gene expression, whereas a complete gene knock out of the candidate gene would have a more drastic effect. The amount of S- and G-units differs greatly between the studies and genes investigated, but there is a general tendency for an overall reduction in S-units. Most studies show that reducing COMT gene expression primarily affects the formation of S-units. One study [72] showed that downregulating the $C A D$ gene in maize does not result in lignin reduction. This could be due to compensation by other $C A D$ genes. Additionally, the expected pigmented phenotype does not appear in any of the grass species when $C A D$ is downregulated; it was only observed in COMT-downregulated plants. This is in contrast to naturally-occurring low-lignin mutants where both cad and comt mutants exhibit the pigmented phenotype [26]. 
Table 1. Transgenic grasses with regulated gene expression in monolignol biosynthesis. The table summarises changes in Klason lignin (KL) or acetyl bromide lignin (ABL) content and changes in the composition of lignin polymer with regards to the amount of syringyl (S), guaiacyl $(\mathrm{G})$ and $p$-hydroxyphenyl $(\mathrm{H})$ units. Notes on other properties affected by gene expression are included, such as a change in growth, resistance, other compounds (mainly ferulic acid (FA) and $p$-coumaric acid $(p C A)$ ), saccharification based on sugar release, pigmented phenotype and other traits highlighted. The abbreviations for genes are the same as those listed in Figure 1; n.a.: data not available; $\uparrow:$ increased, $\downarrow$ : reduced, $=$ : no change compared to wild type.

\begin{tabular}{|c|c|c|c|c|c|c|}
\hline Gene & Species & Method & Lignin Content & $\mathrm{S}, \mathrm{G}, \mathrm{H}$ & Key Features & References \\
\hline$P A L$ & Brachypodium & RNAi & $\downarrow 43 \%(\mathrm{KL})$ & $\uparrow S, \downarrow G, \uparrow H$ & $\begin{array}{l}\downarrow \text { growth, } \downarrow \text { pathogenic } \\
\text { resistance, } \\
\uparrow \text { saccharification, } \downarrow \text { FA, } \\
\downarrow p \text { CA }\end{array}$ & [50] \\
\hline PTAL1 & Brachypodium & RNAi & $\downarrow 43 \%$ & $\downarrow S, \uparrow \mathrm{G}, \uparrow \mathrm{H}$ & $\begin{array}{c}\downarrow \text { flavone and flavonol } \\
\text { derivatives, } \uparrow \mathrm{FA}, \\
\downarrow 4 \mathrm{CA}\end{array}$ & [32] \\
\hline $\mathrm{C} 4 \mathrm{H}-3$ & Maize & asRNA & $\downarrow 14-17 \%$ (ABL) & n.a. & $\begin{array}{l}\text { n.a. } \\
\text { Pigmented phenotype, }\end{array}$ & [51] \\
\hline $4 C L-1$ & Switchgrass & CRISPR/Cas9 & $\downarrow 8-30 \%(\mathrm{ABL})$ & $\downarrow S, \downarrow G,=\mathrm{H}$ & $\begin{array}{c}\uparrow \text { saccharification, } \uparrow \mathrm{FA}, \\
\uparrow p \mathrm{CA}, \text { linkage bonds } \\
\text { changed }\end{array}$ & [52] \\
\hline $4 C L-1$ & Switchgrass & RNAi & $\downarrow 22 \%$ & $=\mathrm{S}, \downarrow \mathrm{G}, \uparrow \mathrm{H}$ & $\begin{array}{c}\text { =growth, pigmented } \\
\text { phenotype, } \\
\uparrow \text { saccharification } \\
\downarrow \text { growth, sterility }\end{array}$ & [53] \\
\hline $\mathrm{C} 3 \mathrm{H}-1$ & Maize & RNAi & $\downarrow 22 \%(\mathrm{KL})$ & $\downarrow S, \downarrow G, \uparrow \mathrm{H}$ & $\begin{array}{c}\uparrow \text { saccharification, } \\
\uparrow \begin{array}{c}\text { anthocyanins, } \uparrow F A, \\
\text { tricin }\end{array}\end{array}$ & [54] \\
\hline $\mathrm{C} 3 \mathrm{H}$ & Rice & RNAi & $\downarrow 30 \%(\mathrm{KL})$ & $\downarrow S, \downarrow G, \uparrow \mathrm{H}$ & $\begin{array}{c}=\text { growth, } \\
\uparrow \text { saccharification, } \downarrow \text { FA, } \\
\uparrow p \text { CA, } \uparrow \text { tricin }\end{array}$ & [55] \\
\hline $\mathrm{C} 3 \mathrm{H}$ & Rice & CRISPR & n.a. & n.a. & $\begin{array}{l}\downarrow \text { growth, } \uparrow \text { death } \\
\text { before maturity }\end{array}$ & [55] \\
\hline F5H & Brachypodium & Overexpression & $\downarrow 18 \%(\mathrm{KL})$ & $\uparrow S, \downarrow G, \uparrow \mathrm{H}$ & $\uparrow$ saccharification & [56] \\
\hline $\mathrm{F} 5 \mathrm{H}$ & Rice & RNAi/overexpressior & $\begin{array}{l}\uparrow / \\
=\end{array}$ & $\begin{array}{l}\downarrow \mathrm{S}, \uparrow \mathrm{G},=\mathrm{H} / \\
\uparrow \mathrm{S}, \downarrow \mathrm{G},=\mathrm{H}\end{array}$ & $\begin{array}{c}=\text { growth, }=\mathrm{FA}, \\
=p \mathrm{CA} / \downarrow \text { growth, } \\
\uparrow \text { sterility, }=\mathrm{FA}, \downarrow p \mathrm{CA}\end{array}$ & [57] \\
\hline $\mathrm{F} 5 \mathrm{H}$ & Rice & CRISPR & $\uparrow 25 \%$ & $\downarrow S, \uparrow G,=H$ & $\begin{array}{c}\text { =growth, } \\
=\text { saccharification, } \\
\uparrow F A,=p C A\end{array}$ & [58] \\
\hline $\mathrm{F} 5 \mathrm{H}$ & Sugarcane & RNAi & $=$ & $\downarrow S, \uparrow G$ & $\begin{array}{c}=\text { growth, } \\
\uparrow \text { saccharification }\end{array}$ & [59] \\
\hline ССоAOMT-2 & Maize & Overexpression & $\uparrow$ & n.a. & $\begin{array}{l}\text { } p \text { pathogenic } \\
\text { resistance }\end{array}$ & [60] \\
\hline CCoAOMT & Maize & RNAi & $\downarrow 22.4 \%(\mathrm{KL})$ & $\uparrow S, \downarrow G$ & $\begin{array}{c}=\text { growth, } \\
\uparrow \text { saccharification }\end{array}$ & [61] \\
\hline CCoAOMT & Sugarcane & RNAi & $=$ & n.a. & $\begin{array}{c}\text { =growth, } \\
\uparrow \text { saccharification } \\
b m \text { phenotype }\end{array}$ & [59] \\
\hline$C C R-1$ & Maize & RNAi & $\downarrow 7-8.7 \%(\mathrm{KL})$ & n.a. & $\begin{array}{c}=\text { growth, } \\
\uparrow \text { saccharification }\end{array}$ & [62] \\
\hline COMT6* & Brachypodium & amiRNA & $\downarrow 24-31.5 \%$ (ABL) & $\downarrow S, \downarrow G,=H$ & $\begin{array}{l}\text { Earlier flowering time, } \\
\uparrow \text { saccharification }\end{array}$ & [63] \\
\hline
\end{tabular}


Table 1. Cont.

\begin{tabular}{|c|c|c|c|c|c|c|}
\hline Gene & Species & Method & Lignin Content & $\mathrm{S}, \mathrm{G}, \mathrm{H}$ & Key Features & References \\
\hline COMT-1,2 & Barley & RNAi & $\downarrow 7-15 \%(\mathrm{KL})$ & $\downarrow \mathrm{S}, \uparrow \mathrm{G},=\mathrm{H}$ & $\begin{array}{c}\uparrow \text { saccharification, } \\
\downarrow p C A,=\text { FA }\end{array}$ & {$[64]$} \\
\hline COMT & Maize & $\begin{array}{c}\text { Antisense } \\
\text { downregulation }\end{array}$ & $\downarrow \sim 17 \%$ & n.a. & $\begin{array}{c}b m \text { phenotype, } \\
\uparrow \text { saccharification }\end{array}$ & [65] \\
\hline COMT & Maize & $\begin{array}{c}\text { Antisense } \\
\text { downregulation }\end{array}$ & $\downarrow 25-30 \%(\mathrm{KL})$ & $\downarrow S, \uparrow G, \downarrow H$ & $\begin{array}{c}b m \text { phenotype, } \\
\uparrow \text { saccharification, } \\
\downarrow p \mathrm{CA},=\mathrm{FA}\end{array}$ & [66] \\
\hline COMT & Sugarcane & RNAi & $=$ & $\downarrow S, \uparrow G$ & $\begin{array}{c}\text { = growth, } \\
\uparrow \text { saccharification }\end{array}$ & [59] \\
\hline COMT & Sugarcane & RNAi & $\downarrow 4-14 \%$ (ABL) & $\downarrow S,=G$ & $\begin{array}{c}\downarrow \text { growth, pigmented } \\
\text { phenotype, } \\
\uparrow \text { saccharification }\end{array}$ & [67] \\
\hline COMT & Sugarcane & RNAi & $\downarrow 6-12 \%(\mathrm{ABL})$ & $\downarrow S, \uparrow G$ & $\begin{array}{c}\downarrow \text { growth, } \\
\uparrow \text { saccharification, } \\
=\mathrm{FA}, \downarrow p \mathrm{CA}\end{array}$ & [68] \\
\hline COMT & Sugarcane & TALEN & $\downarrow 29-32 \%(\mathrm{ABL})$ & $\downarrow S,=G$ & $\begin{array}{c}\downarrow \text { growth, pigmented } \\
\text { phenotype, } \\
\uparrow \text { hemicellulose }\end{array}$ & [69] \\
\hline COMT & Switchgrass & RNAi & $\downarrow 11-16 \%$ & $\downarrow$ & $\begin{array}{l}\text { =growth, } \\
\text { } \text { saccharification, } \\
\text { = pathogenic } \\
\text { resistance } \\
\text { = growth, } b m r\end{array}$ & [70] \\
\hline COMT & Switchgrass & RNAi & $\downarrow 8-9 \%(\mathrm{ABL})$ & $\downarrow S,=G$ & $\begin{array}{c}\text { phenotype, } \\
\uparrow \text { saccharification }\end{array}$ & [71] \\
\hline COMT & Switchgrass & RNAi & $\downarrow 11-13 \%$ (ABL) & $\downarrow S, \downarrow G$ & $\begin{array}{c}\text { =growth, } \mathrm{bmr} \\
\text { phenotype, } \\
\uparrow \text { saccharification }\end{array}$ & [22] \\
\hline$C A D 1$ & Brachypodium & amiRNA & $=(\mathrm{ABL})$ & $\downarrow S, \uparrow G, \uparrow H$ & $\begin{array}{c}\uparrow \text { growth, delayed } \\
\text { flowering, pigmented } \\
\text { phenotype, } \\
\uparrow \text { saccharification }\end{array}$ & [63] \\
\hline$C A D$ & Maize & RNAi & $=(\mathrm{KL})$ & $\downarrow S, \uparrow G, \uparrow H$ & $\begin{array}{c}=\text { growth, } \\
\uparrow \text { saccharification }\end{array}$ & [72] \\
\hline$C A D$ & Rice & RNAi & n.a. & n.a. & $\begin{array}{l}g h \text { phenotype } \\
\text { =growth, }\end{array}$ & [73] \\
\hline$C A D$ & Switchgrass & RNAi & $\downarrow 14-22 \%(\mathrm{ABL})$ & $\downarrow S, \downarrow G$ & $\begin{array}{c}\uparrow \text { saccharification, } \\
=p \mathrm{CA}\end{array}$ & [23] \\
\hline$C A D$ & Switchgrass & RNAi & $\downarrow 23 \%$ & $\downarrow S, \downarrow G$ & $\uparrow$ saccharification & [74] \\
\hline
\end{tabular}

* BdCOMT6 (Bradi3g16530) was named BdCOMT4 in the paper [63]. However, based on the accession number and naming in other papers $[75,76]$, BdCOMT6 was chosen. RNAi: RNA interference.

\section{Mutants with Reduced Lignin}

Naturally-occurring mutants with reduced lignin were identified in cereals such as barley and maize in the early 20th century [77-79]. The mutants are recognised by colour differences: an orange pigmentation occurs in node, lemma and rachis of barley ( $r o b)$ mutants [80], in maize mutants a brown midrib is recognised in the leaves, hence the name 'brown midrib' (bm) [81], and rice mutants called 'gold hull and internode' (gh) exhibit a reddish brown pigmentation in the hull and internode [82]. Furthermore, induced mutants with a similar phenotype to $b m$ maize have also been identified in sorghum brown midrib (bmr) mutants and the model plant Brachypodium [83,84]. Firstly, brown midrib mutants of maize and sorghum were investigated and marketed for ease of forage digestibility $[85,86]$. With the development of plant molecular biology, the genes responsible for the phenotype have been identified and several biochemical analyses performed [26]. Additionally, low lignin mutants are of great interest in bioethanol production as a replacement for fossil fuel [87]. The sections below give an overview for selected grasses.

\subsection{Maize Brown Midrib (bm)}

Maize (Zea mays L.) carrying $b m$ mutations are by far the most studied species of all cereals identified with this phenotype. This is because maize silage is an important feed source for dairy cows and other animals. Improving feeding value can affect dairy production and is therefore of high agronomic interest. The first evidence of the positive effect of $b m$ mutants on feeding value was 
obtained in 1971 [88], and since then analysis has expanded, mostly focusing on the $b m 3$ mutation. Data concerning feeding efficiency of $b m 3$ mutants from 1976-2017 have been combined and presented in a newly published review paper by [89]. They conclude that a diet based on bm3 hybrids has an overall beneficial impact on milk production by dairy cows and reduces the need for energy concentrates. Additionally, knowledge of the impact of other $b m$ mutants on cell wall digestibility is still of interest. In total six bm mutants have been identified [90,91] and listed in the MaizeGDB database (www.maizegdb.org). A literature search resulted in 191 studies on $b m$ mutants, with 60 papers focusing only on $b m 3$ mutants and just a few on the other mutations. However, some studies investigate several mutants and include double mutants for comparison purposes $[17,92,93]$. With regards to review papers, previous publications have already discussed identified $b m$ mutants and they can roughly be divided into three focus areas: (1) animal feed [89,94-96], (2) bioenergy [97] and (3) biochemical properties and molecular analysis [26,96], with some combining all three subjects [98]. The most recent review published by [89] describes the function of all six $b m$ and provides an in-depth analysis of data in relation to animal fodder for $b m 3$. However, a short overview of each $b m$ is given below.

\subsection{1. $b m 1$}

This $b m$ was the first to be identified in maize. The phenotype/trait was discovered by the distinguishable orange/brown midrib in the leaves at three different events $[77,99,100]$ and was described as a simple Mendelian recessive trait. With the discovery of other $b m$ loci, it was renamed $b m 1$. The $b m 1$ locus was mapped to chromosome 5 and co-segregates with the CAD2 (Zm00001d015618) gene [101]. It has been argued that $b m 1$ only affects the expression of the $C A D 2$ gene and is not a null mutation. However, it is only recently that $b m 1$ has finally linked with the $C A D 2$ gene by sequencing and several different mutations (alleles) in the gene have been identified as being responsible for the phenotype [102]. Phenotypic properties of $b m 1$ mutants are reduced lignin content, reduced S- and G-units, reduced FA and $p$-CA, increased aldehydes, change in linkage bonds and normal growth as reviewed in $[89,102]$, as well as agronomic properties of increased digestibility and bioethanol.

\subsection{2. $b m 2$}

First described in 1932 by Burnham and Brink [103], bm2 was mapped fairly recently to the methylenetetrahydrofolate reductase (MTHFR, GRMZM2G347056, EC 1.5.1.20) gene at chromosome 1 [81] localised in the cytoplasm [104]. Briefly, MTHFR affects methylation of S-adenosyl-L-methionine (SAM) in the methionine cycle, which acts as a methyl donor for CCOAOMT and COMT and thereby the formation of G- and S-units $[81,105,106]$. Regulating MTHFR thus affects the accumulation of both Gand S-units, described by [81]. The $b m 2$ mutant is caused by a miniature inverted-repeat transposable element (MITEs) insertion, thereby downregulating the function of MTHFR [107]. They observed an altered lignin composition in reduced G- (and C-) units, with little change in S-units, which did not affect the total amount of bromide acetyl lignin or growth. It also led to a significant improvement in cell wall saccharification efficiency. Other studies have also observed reduced lignin content and alteration with an increased S:G ratio caused by greatly reduced G-units, a slight increase or unchanged $S$ units and unaffected H-units, reviewed in [26]. Moreover, it has been observed that the $b m 2$ mutant has the lowest susceptibility to fungus Ustilago maydis infection compared to $b m 1, b m 3$ and $b m 4$ mutants [17].

\subsection{3. $b m 3$}

Maize $b m 3$ was described in 1935 [78] and later linked to chromosome 4, affecting the COMT (Zm00001d049541) gene owing to two different mutation events $[108,109]$. The $b m 3$ is by far the most studied brown midrib mutant, probably because of its improved feeding values for cattle. It is closely associated with reduced lignin and improved digestion efficiency. The $S: G$ ratio is greatly reduced with $p$-coumarates. Agronomic traits and chemical properties for this mutant have been reviewed very recently [89]. However, there have been no reports on any negative impact associated with $b m 3$, 
except for one study which shows that the $b m 3$ mutant has the highest susceptibility for fungal infection when compared to $b m 1, b m 2$ and $b m 4$ mutants [17].

\subsection{4. $b m 4$}

Maize $b m 4$ was first described by [110] and has been mapped to a putative folylpolyglutamate synthase (FPGS, GRMZM2G393334, EC 6.3.2.17) gene at chromosome 9 and expressed in the cytoplasm [104]. FPGS catalyses the polyglutamylation of tetrahydrofolate (THF), which subsequently catalyses bm2-encoded MTHFR, thus affecting the formation of G- and S-units, similar to $b m 2$ mutants. The $b m 4$ mutant is caused by polymorphism in the form of deletions, resulting in a frameshift and premature stop codons. Furthermore, expression analysis indicates that the $b m 4$ allele is leaky [104]. The effects of $b m 2$ and $b m 4$ are correlated [111], however the review by Sattler, Funnell-Harris and Pedersen [26] concludes that they only have modest changes in lignin composition. With regards to biofuel production, a slight increase in glucose release with acid and base pretreatment has been observed for $b m 4$, however, the amount is still lower compared to the $b m 3$ mutant [93]. Moreover, the $b m 4$ mutant has a reduced defence barrier for pathogenic infection [17].

\subsection{5. $b m 5$}

This natural mutation $b m 5$ was identified by [112]. It has not yet been linked with a gene, only mapped to chromosome 5 close to $b m 1$, but not allelic [113]. There have not been many studies on bm5. One study by Mechin, Laluc, Legee, Cezard, Denoue, Barriere and Lapierre [113] observed an increase in $\mathrm{H}$ - and S-units with a reduction of G- units, changing the lignin composition, and a reduction in Klason lignin was quantified. Additionally, reduced $p C A$ but increased feruloyl esters were linked to the lignin polymer. Finally, it has been suggested that $b m 5$ is linked to the cinnamoyl CoA reductase gene, based on the incorporation of FA and thereby an increase in the weak bis 8-O-4 acetal linkage bonds [113], which can be associated with CCR deficiency [114].

\subsection{6. $b m 6$}

This was first identified by [112] and later mapped to chromosome 2 near bin 2.02 [115]. Only a few analyses have been conducted on $b m 6$, but it exhibits reduced height and increased cell wall digestibility [115].

\subsubsection{Double Mutants}

Several double mutants have been created. They often have adverse growth performances and decreased defence barriers compared to single mutants, however, the rate depends on mutant combination. The defence barrier for fungal infection is substantially reduced for $b m 3-b m 4$, compared to $b m 2-b m 3$ and single mutants, however $b m 2$ has a similar infection rate to wild type [17]. In terms of growth performance, double mutants $b m 2-b m 4$ show severely reduced growth and a significantly low maturity rate compared to other double and single mutants, including a reduced lignin content and a reduction in both S- and G-units. In addition, this double mutant also displays a darker brown midrib [111]. Investigations were conducted before $b m 2$ and $b m 4$ were linked to a specific gene.

\subsection{Barley Orange Lemma (rob1)}

Barley (Hordeum vulgare L.) mutants linked with reduced lignin exhibit an orange colouration in internode, lemma, palea and rachis (Figure 3), hence the locus name "Orange lemma 1" and locus symbol rob1. The mutants carrying this phenotype have been identified on several occasions, from both spontaneous and induced mutations (Barley Genetic Newsletter BGS254) [80]. Additionally, germplasm is stored and accessions can be obtained from the U.S. National Plant Germplasm System (https://www.ars-grin.gov/npgs/index.html). Even though the rob1 mutants have been known for almost a century, only a few studies have investigated its utility with regards to animal 
feed or biofuel production [116-118]. This is in spite of barley being ranked fourth in cereal production and thus being a major lignocellulosic source. The greatest production is in Europe and Russia, but it is also grown worldwide. It is mainly produced for its nutritional grains for human consumption, animal feed or as malt, with the straw used for animal bedding in rural areas or mostly considered as a waste product [119].

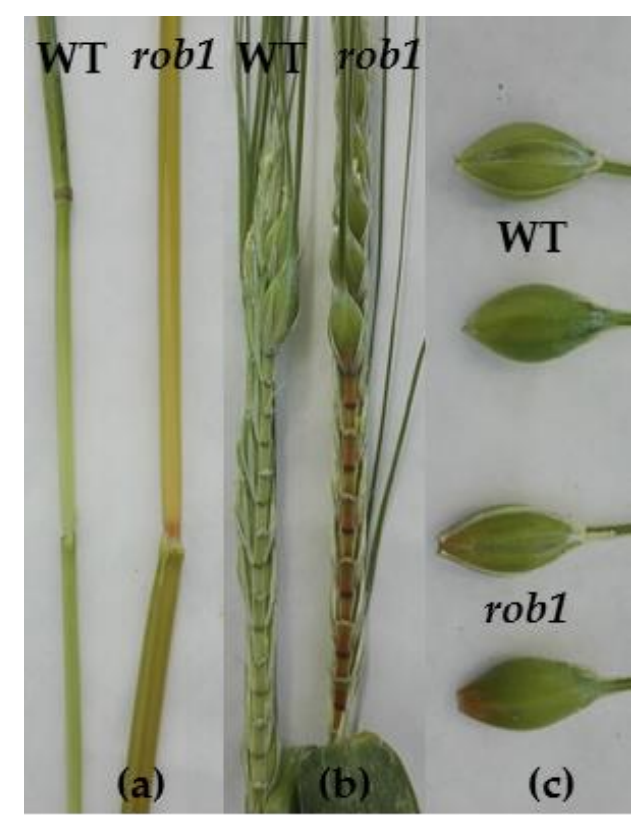

Figure 3. Picture of wild type (WT) barley cv. Golden Promise and barley rob1 mutant (Rob 13/33) displaying the orange lemma phenotype. (a) Stem, rob1 shows orange-coloured internodes, (b) spike, rob1 shows brown rachis and (c) central spikelet, rob1 show orange/brown palea and lemma close to rachis.

rob1

Rob1 was initially used in inheritance studies and considered to be monofactorial recessive following Mendel with a 3:1 ratio [79,120]. The mutation is located on chromosome 6 near the male-sterile 36 locus and the uniculm 2 locus [121] and used as a morphological markers [122-124]. With regards to chemical analysis, one published poster presents the results of rob1 forage quality, however no differences have been identified between the mutant and the elite cultivars [117], despite measurement of lignin content being 10-15\% lower in rob1 mutants of different backgrounds, as well as altered lignin composition with decreased S:G ratio and increased saccharification efficiency compared to wild type [116,118]. The rob1 is mapped to the HvCAD2 gene, similar to $b m 1$ in maize [116]. However, the detected mutations responsible for the rob1 mutant have not yet been published.

\subsection{Rice Gold Hull and Internode (gh)}

Rice (Oryza sativa L.) displaying the gold hull and internode (gh) phenotype has been identified in a number of mutants ( $g h 1, g h 2, g h 3$ and $g h 4)$ listed in the Oryzabase (https://shigen.nig.ac.jp/ rice/oryzabase/). They are recognised by their reddish-brown pigment in the internode and yellow coloration of the hull. Even though this phenotype was described as early as 1917 [82] and has been used as a marker for a long time [125], it is only recently that a few studies have investigated the genetics behind $g h 1$ and $g h 2$ and undertaken biochemical analysis with regards to lignin [82,126,127]. Rice is the second most produced cereal after maize, and it is estimated to be the staple food for one-fifth of the world's population [128]. It is mainly grown in Asia for its grain and its straw is generally used as a waste product. Furthermore, little is used for compost and only a small portion is used for 
animal feed, conceivably because the leaves are simply too sharp to be used as animal feed due to their high silicon content. This is a major lignocellulosic source with great potential for utilisation to make various products such as biofuel [129] and byproducts. Therefore, it is suggested that more research on gh mutants is needed.

\subsection{1. $g h 1$}

Rice gh1 is mapped to the chalcone isomerase (CHI, Os03g 0819600, EC 5.5.1.6) gene on chromosome 3 with a Dasheng retrotransposon inserted causing loss of function [127]. However, this gene is part of the flavonoid pathway, which is derived from the general phenylpropanoid pathway as well as the monolignol pathway [127]. Briefly, the CHI enzyme converts naringenin chalcone, a yellow pigment, into naringenin, and an accumulation of this product causes a yellow pigmentation [126,130]. Since both the flavonoid pathway and the monolignol pathway use the same precursors, one study investigated whether the gh1 mutant has an effect on lignin formation [126]. Its results showed an increased saccharification efficiency and altered lignin composition with a reduced S:G ratio caused by significantly reduced S-units and increased H- and G-units (and FA). Lignin content differed depending on the extraction method, with reduced thioglycolic lignin content but no change in Klason lignin compared to wild type. Additionally, the gh1 mutant shows no reduction in biomass or lodging resistance, however reduced grain yield has been reported. This indicates that regulation of genes in the flavonoid pathway affects monolignol formation and lignin composition.

\subsection{2. $g h 2$}

Rice gh2 phenotype is caused by mutations in the CAD2 gene (Os02g0187800) on chromosome 2. The original spontaneous $g h 2$ mutant (Zhefu802) is caused by a point mutation in exon 4 which changes expression level and exhibits the $g h$ phenotype [82], while the gh2 mutant line created with Tos17 insertion in exon 2 is a null mutant (https://tos.nias.affrc.go.jp/) and displays the $b m$ phenotype [73]. Expression analysis of the original gh2 shows reduced CAD and SAD activity differentiating between tissues, which indicates an additional function of CAD-isoenzymes. Klason lignin content is only slightly reduced, even though a dramatic reduction is shown for lignin monomers [82]. Additionally, the Tos17-generated gh2 mutant shows less lignin and increased saccharification efficiency compared to both wild type and spontaneous gh2 mutant. Furthermore, H- and S-units are also significantly reduced [73]. These two studies indicate the importance of the location of the mutation on the gene. For future research, biomass, grain yield and lodging resistance need to be investigated in order to evaluate the potential of $g h 2$ as a biofuel crop.

\subsection{Sorghum Brown Midrib (bmr)}

Sorghum (Sorghum bicolor (L.) Moench) brown midrib (bmr) mutants exhibit a similar phenotype to $b m$ maize. As the name indicates, a brown coloration in the midrib of leaves is exhibited. The first identified $b m r$ mutants were developed via chemical mutagenesis using diethyl sulfate in 1978. Nineteen $b m r$ mutants were identified and six mutants $(b m r 2, b m r 6, b m r 12, b m r 14, b m r 18$ and bmr19) had a significantly reduced lignin compared to wild type [84]. Later, spontaneous bmr mutants were also identified by Dr. Gebisa Ejeta (Purdue University, unpublished results) and described in $[131,132]$ and listed consecutively $b m r$ 1-28 including the induced $b m r$ mutants $[87,133,134]$. Additionally, a TILLING (Targeting Induced Local Lesions in Genomes) population was examined and even more $b m r$ mutants identified $[131,135,136]$. Allelism tests have been performed and four allelic classes identified - $b m r 2, b m r 6, b m r 12$, and $b m r 19$ - with $b m r 6$ and $b m r 12$ being the most widely used in breeding programmes $[132,137]$. Bmr19 has been reported as having insignificantly reduced lignin and is therefore not of interest to the forage industry [132]. It will therefore not be discussed further in this review. Hence, many $b m r$ mutants have been identified and linked to the same locus. In order to obtain a better overview, they have been organised by additional numbers (see [131]). Sorghum is ranked fifth in cereal production. It is mainly distributed in arid areas of Africa, Central America and South Asia, 
where it is grown for its grains utilised by humans or as silage for animal feed. Additionally, the stems are used for alcoholic beverages. Considerable research and biochemical analysis have been conducted on $b m r$ mutants with regards to both silage and biofuel production. For farmers, the $b m r$ phenotype is a visual marker that can be observed in the field to verify the quality trait. A literature search resulted in more than 200 papers published since 1978 when the first $b m r$ mutants were developed [84]. Furthermore, many reviews have focused on digestion efficiency, lignin composition and improved saccharification $[21,26,86,87,138,139]$. Here $b m r 2, b m r 6$ and $b m r 12$ are presented.

\subsection{1. bmr2 Group}

Sorghum $b m r 2$ group, which includes $b m r 2, b m r 5$ and $b m r 14$, shows a reduction in both G- and S-units, which are all described in [132]. Bmr2 is the most studied of the three mutants and described as two different alleles bmr2-ref [132] and bmr2-2 [135]. The bmr2 gene encodes 4CL located on chromosome 4 , and sequencing reveals two point mutations within the coding sequence responsible for the phenotype. However, the gene $4 C L$ is part of a family with several isoforms varying in expression regulating different substrates. For a detailed description see [140].

\subsection{2. bmr6 Group}

Sorghum bmr6 group includes bmr3, 4, 6, 20, 22-24, 27 and 28 [132]. The bmr6 phenotype was mapped to the CAD2 (Sb04g005950) gene on chromosome 4 [141], and different mutations responsible for the bmr6 phenotype have been revealed by sequencing, resulting in premature STOP-codon or loss of important catalytic domains [141-143]. Reduced CAD2 activity resulted in decreased lignin content with low amount of G-units and increased level of cinnamaldehydes $[144,145]$. Another study observed a significant reduction in all lignin subunits, particularly S-units resulting in reduced S:G ratio [142] In-depth knowledge of the chemical composition, improved saccharification efficiency and decreased lignin content of $b m r 6$ and $b m r 12$ question whether the $S: G$ ratio is a valid indicator for lignin recalcitrance and it has been concluded that more knowledge is needed [146]. In terms of agronomic values, lodging is not affected by bmr6 in either forage [147] or grain sorghum [148], although negative effects on biomass have been reported for forage sorghum [147] and grain yield in grain sorghum [148]. Despite these negative effects, in terms of diets for dairy cows the bmr6 forage sorghum performs better than wild type [149].

\subsection{3. bmr12 Group}

The sorghum bmr12 group includes $b m r 7,12,15,18,25$ and 26 [132] and are all mapped to the COMT gene with premature stop codons giving rise to the $b m r$ mutants [150]. Other mutations have also been identified for bmr12 mutants and characterised by [151]. Overall, the bmr12 mutants in biomass sorghum all have reduced lignin and generally contribute positively to bioconversion and digestion efficiency [139]. However, negative impacts on agronomical traits have also been reported, such as reduced yield in grain sorghum [148] and biomass in forage sorghum [147], and thus do not affect susceptibility to disease [18]. However, a recent study concludes that weather conditions have a greater impact and in some cases free phenolic compounds even act as a defence mechanism, depending on the diseases reviewed [152].

\subsection{Pearl Millet}

Pearl millet (Pennisetum glaucum L.) is a highly drought-tolerant annual forage plant that is utilised for grain production or as silage for animal feed.

Three brown midrib mutants have been identified in pearl millet, which assembles the same colouration as $b m$ maize and $b m r$ sorghum. The mutations occurred spontaneously or were induced using dimethyl sulfate. However, only a few studies have investigated the properties of these mutant lines. The agronomic potential is reviewed by [26] and they conclude that a significant yield reduction is associated with $b m r$ pearl millets and is therefore not of interest as breeding material. 


\subsection{Brachypodium}

Brachypodium distachyon (Brachypodium) is a small grass with a relatively short growing season. It is diploid and the genome is fully sequenced and similar in size to rice. It is therefore used as a model plant for grasses [153].

A chemically-induced mutant population of Brachypodium was developed with a TILLING platform [75]. Several lines were identified with induced mutations in genes involved in the lignin biosynthesis such as $C 4 \mathrm{H}, 4 \mathrm{C}$, and COMT. The same study analysed the effect of mutations in the COMT6 (Bradi3g16530) gene on lignin content and composition in several lines. They discovered reduced Klason lignin and altered composition with a decreased S:G ratio, where S-units were significantly reduced and G-units increased. This corresponds with $b m 3$ and bmr12 COMT-deficient plants $[89,151]$. Further studies have been performed on line Bd5139, which had a missense mutation in the COMT6 gene, and revealed a reduction in $p$ CA esterified to S-units. However, $p C A$ linked to arabinoxylans was not affected, which substantiates comt 6 affinity for $p$ CA ester-linkage to S-units [76]. Another study also used chemical mutagenesis to create mutations in Brachypodium plants and lignin-deficient mutants were identified by a brownish/red colouration in nodes, lemma and rachis [83]. An SNP mutation was identified in the CAD1 gene (Bradi3g06480) causing the phenotype; interestingly it was identical to the sorghum bmr6-3 [141]. Overall the mutant shows reduced lignin and altered composition, which is similar to what has been observed in other species. Furthermore, a coexpression database (www.gene2function.de) has been developed for important genes involved in the lignification of the cell wall in many organs at different developmental stages in Brachypodium [56].

\section{Conclusions}

Lignocellulosic material from grasses is an essential source for bioethanol production and/or animal fodder. However, the recalcitrant structure of lignin limits decomposition and hence utilisation of the embedded cellulose fibrils. Naturally-occurring low-lignin mutants have been identified in several species and investigations show the great potential in promoting these mutants. So far, however, only $b m$ maize and $b m r$ sorghum containing mutations have been commercialised. Promoting $g h$ rice and rob1 barley would extend the feedstock source for animals, bioenergy and the emerging circular bioeconomy. Based on existing knowledge about $b m$ maize and $b m r$ sorghum, it is predicted that there is great potential for improving and developing new commercial varieties of rob1 barley and $g h$ rice with improved utilisation. Furthermore, results from various genetic manipulations of genes in the lignin biosynthesis offers detailed information about the function and its potential for further modification in future research. However, down-regulating genes by antisense/RNAi only provides valid information about gene function and is not useful in breeding. Instead, chemical mutagenesis and CRISPR/Cas9 have the potential to create stable mutations with loss of function, which resembles the natural low-lignin mutants. It has been predicted that CRISPR/Cas9 will revolutionise precision breeding, however there has been a declaration that it now comes under GMO regulations in the EU [45], which complicates the use of this technology. Instead, the screening of existing germplasm is suggested with the use of TILLING to identify new mutations in order to overcome current regulatory difficulties with regard to crop improvements.

Author Contributions: S.K.R. conceived and outlined the manuscript and C.S.L.C. drafted the manuscript, prepared the figures and table. Both S.K.R. and C.S.L.C. finalised the manuscript.

Funding: This research was funded by the Sino-Danish Center.

Conflicts of Interest: The authors declare no conflict of interest.

\section{References}

1. Anwar, Z.; Gulfraz, M.; Irshad, M. Agro-industrial lignocellulosic biomass a key to unlock the future bio-energy: A brief review. J. Rad. Res. Appl. Sci. 2014, 7, 163-173. [CrossRef] 
2. Guerriero, G.; Hausman, J.F.; Strauss, J.; Ertan, H.; Siddiqui, K.S. Lignocellulosic biomass: Biosynthesis, degradation, and industrial utilization. Eng. Life Sci. 2016, 16, 1-16. [CrossRef]

3. FAO. Global Cereal Production and Inventories to Decline but Overall Supplies Remain Adequate. Available online: www.fao.org/worldfoodsituation/csdb/en/ (accessed on 7 December 2018).

4. Graham-Rowe, D. Agriculture: Beyond food versus fuel. Nature 2011, 474, 6-8. [CrossRef]

5. Vogel, J. Unique aspects of the grass cell wall. Curr. Opin. Plant Biol. 2008, 11, 301-307. [CrossRef]

6. Doblin, M.S.; Pettolino, F.; Bacic, A. Plant cell walls: The skeleton of the plant world. Funct. Plant Biol. 2010, 37, 357-381. [CrossRef]

7. Iqbal, H.M.N.; Kyazze, G.; Keshavarz, T. Advances in the valorization of lignocellulosic materials by biotechnology: An overview. Bioresources 2013, 8, 3157-3176. [CrossRef]

8. Jorgensen, H.; Kristensen, J.B.; Felby, C. Enzymatic conversion of lignocellulose into fermentable sugars: Challenges and opportunities. Biofuels Bioprod.Biorefin. 2007, 1, 119-134. [CrossRef]

9. Carpita, N.C.; Gibeaut, D.M. Structural models of primary cell walls in flowering plants: Consistency of molecular structure with the physical properties of the walls during growth. Plant J. 1993, 3, 1-30. [CrossRef] [PubMed]

10. Hamant, O.; Traas, J. The mechanics behind plant development. New Phytol. 2010, 185, 369-385. [CrossRef]

11. Harrington, M.J.; Mutwil, M.; Barriere, Y.; Sibout, R. Molecular biology of lignification in grasses. In Lignins: Biosynthesis, Biodegradation and Bioengineering; Jouann, L., Lapierre, C., Eds.; Academic Press-Elsevier: Cambridge, MA, USA, 2012; Volume 61, pp. 77-112.

12. Yu, H.; Liu, R.; Shen, D.; Wu, Z.; Huang, Y. Arrangement of cellulose microfibrils in the wheat straw cell wall. Carbohydr. Polym. 2008, 72, 122-127. [CrossRef]

13. Miedes, E.; Vanholme, R.; Boerjan, W.; Molina, A. The role of the secondary cell wall in plant resistance to pathogens. Front. Plant Sci. 2014, 5, 358. [CrossRef]

14. Vance, C.; Kirk, T.; Sherwood, R. Lignification as a mechanism of disease resistance. Annu. Rev. Phytopathol. 1980, 18, 259-288. [CrossRef]

15. Hammond-Kosack, K.E.; Jones, J. Resistance gene-dependent plant defense responses. Plant Cell 1996, 8, $1773-1791$. [CrossRef] [PubMed]

16. Bhuiyan, N.H.; Selvaraj, G.; Wei, Y.; King, J. Gene expression profiling and silencing reveal that monolignol biosynthesis plays a critical role in penetration defence in wheat against powdery mildew invasion. J. Exp. Bot. 2008, 60, 509-521. [CrossRef]

17. Tanaka, S.; Brefort, T.; Neidig, N.; Djamei, A.; Kahnt, J.; Vermerris, W.; Koenig, S.; Feussner, K.; Feussner, I.; Kahmann, R. A secreted Ustilago maydis effector promotes virulence by targeting anthocyanin biosynthesis in maize. Elife 2014, 3, e01355. [CrossRef]

18. Sattler, S.; Funnell-Harris, D. Modifying lignin to improve bioenergy feedstocks: Strengthening the barrier against pathogens? Front. Plant Sci. 2013, 4, 70. [CrossRef]

19. Vanholme, R.; Morreel, K.; Ralph, J.; Boerjan, W. Lignin engineering. Curr. Opin. Plant Biol. 2008, 11, $278-285$. [CrossRef]

20. Rao, X.; Dixon, R.A. Current models for transcriptional regulation of secondary cell wall biosynthesis in grasses. Front. Plant Sci. 2018, 9, 399. [CrossRef] [PubMed]

21. Pedersen, J.F.; Vogel, K.P.; Funnell, D.L. Impact of reduced lignin on plant fitness. Crop Sci. 2005, 45, 812-819. [CrossRef]

22. Fu, C.; Mielenz, J.R.; Xiao, X.; Ge, Y.; Hamilton, C.Y.; Rodriguez, M.; Chen, F.; Foston, M.; Ragauskas, A.; Bouton, J. Genetic manipulation of lignin reduces recalcitrance and improves ethanol production from switchgrass. Proc. Natl. Acad. Sci. USA 2011, 108, 3803-3808. [CrossRef]

23. Fu, C.; Xiao, X.; Xi, Y.; Ge, Y.; Chen, F.; Bouton, J.; Dixon, R.A.; Wang, Z.-Y. Downregulation of cinnamyl alcohol dehydrogenase (CAD) leads to improved saccharification efficiency in switchgrass. Bioenergy Res. 2011, 4, 153-164. [CrossRef]

24. Bukh, C.; Nord-Larsen, P.H.; Rasmussen, S.K. Phylogeny and structure of the cinnamyl alcohol dehydrogenase gene family in Brachypodium distachyon. J. Exp. Bot. 2012, 63, 6223-6236. [CrossRef]

25. Wu, X.; Wu, J.; Luo, Y.; Bragg, J.; Anderson, O.; Vogel, J.; Gu, Y.Q. Phylogenetic, molecular, and biochemical characterization of caffeic acid O-methyltransferase gene family in Brachypodium distachyon. Int. J. Plant Genom. 2013, 2013, 1-12. [CrossRef] 
26. Sattler, S.E.; Funnell-Harris, D.L.; Pedersen, J.F. Brown midrib mutations and their importance to the utilization of maize, sorghum, and pearl millet lignocellulosic tissues. Plant Sci. 2010, 178, 229-238. [CrossRef]

27. Rösler, J.; Krekel, F.; Amrhein, N.; Schmid, J. Maize phenylalanine ammonia-lyase has tyrosine ammonia-lyase activity. Plant Physiol. 1997, 113, 175-179. [CrossRef]

28. Neish, A.C. Formation of $m$ - and $p$-coumaric acids by enzymatic deamination of the corresponding isomers of tyrosine. Phytochemistry 1961, 1, 1-24. [CrossRef]

29. Boerjan, W.; Ralph, J.; Baucher, M. Lignin biosynthesis. Annu. Rev. Plant Biol. 2003, 54, 519-546. [CrossRef]

30. Faraji, M.; Fonseca, L.L.; Escamilla-Treviño, L.; Barros-Rios, J.; Engle, N.L.; Yang, Z.K.; Tschaplinski, T.J.; Dixon, R.A.; Voit, E.O. A dynamic model of lignin biosynthesis in Brachypodium distachyon. Biotechnol. Biofuels 2018, 11, 253. [CrossRef]

31. Mottiar, Y.; Vanholme, R.; Boerjan, W.; Ralph, J.; Mansfield, S.D. Designer lignins: Harnessing the plasticity of lignification. Curr. Opin. Biotechnol. 2016, 37, 190-200. [CrossRef]

32. Barros, J.; Serrani-Yarce, J.C.; Chen, F.; Baxter, D.; Venables, B.J.; Dixon, R.A. Role of bifunctional ammonia-lyase in grass cell wall biosynthesis. Nat. Plants 2016, 2, 16050. [CrossRef]

33. Grabber, J.H.; Ralph, J.; Hatfield, R.D. Cross-linking of maize walls by ferulate dimerization and incorporation into lignin. J. Agric. Food Chem. 2000, 48, 6106-6113. [CrossRef]

34. Del Río, J.C.; Rencoret, J.; Prinsen, P.; Martínez, A.T.; Ralph, J.; Gutiérrez, A. Structural characterization of wheat straw lignin as revealed by analytical pyrolysis, 2D-NMR, and reductive cleavage methods. J. Agric. Food Chem. 2012, 60, 5922-5935. [CrossRef] [PubMed]

35. Lan, W.; Lu, F.; Regner, M.; Zhu, Y.; Rencoret, J.; Ralph, S.A.; Zakai, U.I.; Morreel, K.; Boerjan, W.; Ralph, J. Tricin, a flavonoid monomer in monocot lignification. Plant Physiol. 2015, 167, 1284-1295. [CrossRef]

36. Lan, W.; Rencoret, J.; Lu, F.; Karlen, S.D.; Smith, B.G.; Harris, P.J.; del Río, J.C.; Ralph, J. Tricin-lignins: Occurrence and quantitation of tricin in relation to phylogeny. Plant J. 2016, 88, 1046-1057. [CrossRef]

37. Ralph, J.; Lundquist, K.; Brunow, G.; Lu, F.; Kim, H.; Schatz, P.F.; Marita, J.M.; Hatfield, R.D.; Ralph, S.A.; Christensen, J.H. Lignins: Natural polymers from oxidative coupling of 4-hydroxyphenyl-propanoids. Phytochem. Rev. 2004, 3, 29-60. [CrossRef]

38. Martinez, P.M.; Punt, A.M.; Kabel, M.A.; Gruppen, H. Deconstruction of lignin linked p-coumarates, ferulates and xylan by $\mathrm{NaOH}$ enhances the enzymatic conversion of glucan. Bioresour. Technol. 2016, 216, 44-51. [CrossRef]

39. Ralph, J.; Hatfield, R.D.; Quideau, S.; Helm, R.F.; Grabber, J.H.; Jung, H.J.G. Pathway of $p$-coumaric acid incorporation into maize lignin as revealed by NMR. J. Am. Chem. Soc. 1994, 116, 9448-9456. [CrossRef]

40. Karlen, S.D.; Zhang, C.; Peck, M.L.; Smith, R.A.; Padmakshan, D.; Helmich, K.E.; Free, H.C.; Lee, S.; Smith, B.G.; Lu, F. Monolignol ferulate conjugates are naturally incorporated into plant lignins. Sci. Adv. 2016, 2, e1600393. [CrossRef]

41. Grabber, J.H.; Hatfield, R.D.; Lu, F.; Ralph, J. Coniferyl ferulate incorporation into lignin enhances the alkaline delignification and enzymatic degradation of cell walls. Biomacromolecules 2008, 9, 2510-2516. [CrossRef] [PubMed]

42. Kumar, M.; Campbell, L.; Turner, S. Secondary cell walls: Biosynthesis and manipulation. J. Exp. Bot. 2016, 67, 515-531. [CrossRef]

43. Saurabh, S.; Vidyarthi, A.S.; Prasad, D. RNA interference: Concept to reality in crop improvement. Planta 2014, 239, 543-564. [CrossRef] [PubMed]

44. Belhaj, K.; Chaparro-Garcia, A.; Kamoun, S.; Patron, N.J.; Nekrasov, V. Editing plant genomes with CRISPR/Cas9. Curr. Opin. Biotechnol. 2015, 32, 76-84. [CrossRef]

45. Court of Justice of the European Union. Case C-528/16. Available online: http://curia.europa.eu/juris/ documents.jsf?num=C-528/16 (accessed on 25 July 2018).

46. Theander, O.; Westerlund, E.A. Studies on dietary fiber. 3. Improved procedures for analysis of dietary fiber. J. Agric. Food Chem. 1986, 34, 330-336. [CrossRef]

47. Morrison, I.M. Improvements in the acetyl bromide technique to determine lignin and digestibility and its application to legumes. J. Sci. Food Agric. 1972, 23, 1463-1469. [CrossRef]

48. Fukushima, R.S.; Hatfield, R.D. Comparison of the acetyl bromide spectrophotometric method with other analytical lignin methods for determining lignin concentration in forage samples. J. Agric. Food Chem. 2004, 52, 3713-3720. [CrossRef] 
49. Fukushima, R.S.; Kerley, M.S.; Ramos, M.H.; Porter, J.H.; Kallenbach, R.L. Comparison of acetyl bromide lignin with acid detergent lignin and Klason lignin and correlation with in vitro forage degradability. Anim. Feed Sci. Technol. 2015, 201, 25-37. [CrossRef]

50. Cass, C.L.; Peraldi, A.; Dowd, P.F.; Mottiar, Y.; Santoro, N.; Karlen, S.D.; Bukhman, Y.V.; Foster, C.E.; Thrower, N.; Bruno, L.C.; et al. Effects of PHENYLALANINE AMMONIA LYSASE (PAL) knockdown on cell wall composition, biomass digestibility, and biotic and abiotic stress responses in Brachypodium. J. Exp. Bot. 2015, 66, 4317-4335. [CrossRef]

51. Abdel-Rahman, M.M.; Mousa, I.E. Effects of down regulation of lignin content in maize (Zea mays L.) plants expressing $C 4 H 3$ gene in the antisense orientation. Biofuels 2016, 7, 289-294. [CrossRef]

52. Park, J.-J.; Yoo, C.G.; Flanagan, A.; Pu, Y.; Debnath, S.; Ge, Y.; Ragauskas, A.J.; Wang, Z.-Y. Defined tetra-allelic gene disruption of the 4-coumarate:coenzyme A ligase 1 (Pv4CL1) gene by CRISPR/Cas9 in switchgrass results in lignin reduction and improved sugar release. Biotechnol. Biofuels 2017, 10, 284. [CrossRef]

53. Xu, B.; Escamilla-Treviño, L.L.; Sathitsuksanoh, N.; Shen, Z.; Shen, H.; Percival Zhang, Y.H.; Dixon, R.A.; Zhao, B. Silencing of 4-coumarate:coenzyme A ligase in switchgrass leads to reduced lignin content and improved fermentable sugar yields for biofuel production. New Phytol. 2011, 192, 611-625. [CrossRef]

54. Fornale, S.; Rencoret, J.; Garcia-Calvo, L.; Capellades, M.; Encina, A.; Santiago, R.; Rigau, J.; Gutierrez, A.; del Rio, J.-C.; Caparros-Ruiz, D. Cell wall modifications triggered by the down-regulation of coumarate 3-hydroxylase-1 in maize. Plant Sci. 2015, 236, 272-282. [CrossRef]

55. Takeda, Y.; Tobimatsu, Y.; Karlen, S.D.; Koshiba, T.; Suzuki, S.; Yamamura, M.; Murakami, S.; Mukai, M.; Hattori, T.; Osakabe, K.; et al. Downregulation of $p$-coumaroyl ester 3-hydroxylase in rice leads to altered cell wall structures and improves biomass saccharification. Plant J. 2018, 95, 796-811. [CrossRef]

56. Sibout, R.; Proost, S.; Hansen, B.O.; Vaid, N.; Giorgi, F.M.; Ho-Yue-Kuang, S.; Legée, F.; Cézart, L.; Bouchabké-Coussa, O.; Soulhat, C. Expression atlas and comparative coexpression network analyses reveal important genes involved in the formation of lignified cell wall in Brachypodium distachyon. New Phytol. 2017, 215, 1009-1025. [CrossRef]

57. Takeda, Y.; Koshiba, T.; Tobimatsu, Y.; Suzuki, S.; Murakami, S.; Yamamura, M.; Rahman, M.M.; Takano, T.; Hattori, T.; Sakamoto, M. Regulation of coniferaldehyde 5-hydroxylase expression to modulate cell wall lignin structure in rice. Planta 2017, 246, 337-349. [CrossRef] [PubMed]

58. Takeda, Y.; Suzuki, S.; Tobimatsu, Y.; Osakabe, K.; Osakabe, Y.; Ragamustari, S.K.; Sakamoto, M.; Umezawa, T. Lignin characterization of rice CONIFERALDEHYDE 5-HYDROXYLASE loss-of-function mutants generated with the CRISPR/Cas9 system. Plant J. 2018, 97, 543-554. [CrossRef]

59. Bewg, W.P.; Poovaiah, C.; Lan, W.; Ralph, J.; Coleman, H.D. RNAi downregulation of three key lignin genes in sugarcane improves glucose release without reduction in sugar production. Biotechnol. Biofuels 2016, 9, 270. [CrossRef]

60. Yang, Q.; He, Y.; Kabahuma, M.; Chaya, T.; Kelly, A.; Borrego, E.; Bian, Y.; El Kasmi, F.; Yang, L.; Teixeira, P.; et al. A gene encoding maize caffeoyl-CoA O-methyltransferase confers quantitative resistance to multiple pathogens. Nat. Genet. 2017, 49, 1364. [CrossRef]

61. Li, X.; Chen, W.; Zhao, Y.; Xiang, Y.; Jiang, H.; Zhu, S.; Cheng, B. Downregulation of caffeoyl-CoA $O$-methyltransferase (CCOAOMT) by RNA interference leads to reduced lignin production in maize straw. Genet. Mol. Biol. 2013, 36, 540-546. [CrossRef] [PubMed]

62. Park, S.-H.; Mei, C.; Pauly, M.; Ong, R.G.; Dale, B.E.; Sabzikar, R.; Fotoh, H.; Thang, N.; Sticklen, M. Downregulation of maize cinnamoyl-coenzyme a reductase via RNA interference technology causes brown midrib and improves ammonia fiber expansion-pretreated conversion into fermentable sugars for biofuels. Crop Sci. 2012, 52, 2687-2701. [CrossRef]

63. Trabucco, G.M.; Matos, D.A.; Lee, S.J.; Saathoff, A.J.; Priest, H.D.; Mockler, T.C.; Sarath, G.; Hazen, S.P. Functional characterization of cinnamyl alcohol dehydrogenase and caffeic acid $O$-methyltransferase in Brachypodium distachyon. BMC Biotechnol. 2013, 13, 61. [CrossRef] [PubMed]

64. Daly, P.; McClellan, C.; Maluk, M.; Oakey, H.; Lapierre, C.; Waugh, R.; Stephens, J.; Marshall, D.; Barakate, A.; Tsuji, Y.; et al. RNAi-suppression of barley caffeic acid $O$-methyltransferase modifies lignin despite redundancy in the gene family. Plant Biotechnol. J. 2018, 17, 549-607. [CrossRef]

65. He, X.; Hall, M.B.; Gallo-Meagher, M.; Smith, R.L. Improvement of forage quality by downregulation of maize O-methyltransferase. Crop Sci. 2003, 43, 2240-2251. [CrossRef] 
66. Piquemal, J.; Chamayou, S.; Nadaud, I.; Beckert, M.; Barriere, Y.; Mila, I.; Lapierre, C.; Rigau, J.; Puigdomenech, P.; Jauneau, A.; et al. Down-regulation of caffeic acid O-methyltransferase in maize revisited using a transgenic approach. Plant Physiol. 2002, 130, 1675-1685. [CrossRef]

67. Jung, J.H.; Fouad, W.M.; Vermerris, W.; Gallo, M.; Altpeter, F. RNAi suppression of lignin biosynthesis in sugarcane reduces recalcitrance for biofuel production from lignocellulosic biomass. Plant Biotechnol. J. 2012, 10, 1067-1076. [CrossRef]

68. Jung, J.H.; Vermerris, W.; Gallo, M.; Fedenko, J.R.; Erickson, J.E.; Altpeter, F. RNA interference suppression of lignin biosynthesis increases fermentable sugar yields for biofuel production from field-grown sugarcane. Plant Biotechnol. J. 2013, 11, 709-716. [CrossRef]

69. Jung, J.H.; Altpeter, F. TALEN mediated targeted mutagenesis of the caffeic acid O-methyltransferase in highly polyploid sugarcane improves cell wall composition for production of bioethanol. Plant Mol. Biol. 2016, 92, 131-142. [CrossRef]

70. Baxter, H.L.; Mazarei, M.; Fu, C.; Cheng, Q.; Turner, G.B.; Sykes, R.W.; Windham, M.T.; Davis, M.F.; Dixon, R.A.; Wang, Z.-Y.; et al. Time course field analysis of COMT-downregulated switchgrass: Lignification, recalcitrance, and rust susceptibility. Bioenergy Res. 2016, 9, 1087-1100. [CrossRef]

71. Liu, S.; Fu, C.; Gou, J.; Sun, L.; Huhman, D.; Zhang, Y.; Wang, Z.-Y. Simultaneous downregulation of MTHFR and COMT in switchgrass affects plant performance and induces lesion-mimic cell death. Front. Plant Sci. 2017, 8, 982. [CrossRef]

72. Fornale, S.; Capellades, M.; Encina, A.; Wang, K.; Irar, S.; Lapierre, C.; Ruel, K.; Joseleau, J.-P.; Berenguer, J.; Puigdomenech, P.; et al. Altered lignin biosynthesis improves cellulosic bioethanol production in transgenic maize plants down-regulated for cinnamyl alcohol dehydrogenase. Mol. Plant 2012, 5, 817-830. [CrossRef]

73. Koshiba, T.; Murakami, S.; Hattori, T.; Mukai, M.; Takahashi, A.; Miyao, A.; Hirochika, H.; Suzuki, S.; Sakamoto, M.; Umezawa, T. CAD2 deficiency causes both brown midrib and gold hull and internode phenotypes in Oryza sativa L. cv. Nipponbare. Plant Biotechnol. 2013, 30, 365-373. [CrossRef]

74. Saathoff, A.J.; Sarath, G.; Chow, E.K.; Dien, B.S.; Tobias, C.M. Downregulation of cinnamyl-alcohol dehydrogenase in switchgrass by RNA silencing results in enhanced glucose release after cellulase treatment. PLOS ONE 2011, 6, e16416. [CrossRef] [PubMed]

75. Dalmais, M.; Antelme, S.; Ho-Yue-Kuang, S.; Wang, Y.; Darracq, O.; d’Yvoire, M.B.; Cézard, L.; Légée, F.; Blondet, E.; Oria, N. A TILLING platform for functional genomics in Brachypodium distachyon. PLoS ONE 2013, 8, e65503. [CrossRef] [PubMed]

76. Ho-Yue-Kuang, S.; Alvarado, C.; Antelme, S.; Bouchet, B.; Cezard, L.; Le Bris, P.; Legee, F.; Maia-Grondard, A.; Yoshinaga, A.; Saulnier, L.; et al. Mutation in Brachypodium caffeic acid O-methyltransferase 6 alters stem and grain lignins and improves straw saccharification without deteriorating grain quality. J. Exp. Bot. 2016, 67, $227-237$. [CrossRef] [PubMed]

77. Jorgenson, L.R. Brown midrib in maize and its lineage relations. ASA 1931, 23, 549-577.

78. Emerson, R.; Beadle, G.W.; Fraser, A.C. A summary of linkage studies in maize. Cornell Univ. Agric. Exp. Stn. Memoir 1935, 180, 1-83.

79. Buckley, G.F.H. Inheritance in barley with special reference to the color of caryopsis and lemma. Sci. Agric. 1930, 10, 460-492. [CrossRef]

80. NordGen. BGS 254, Orange Lemma 1, rob1. Available online: www.nordgen.org/bgs/system/export_pdf.php? bgs $=254$ (accessed on 19 November 2018).

81. Tang, H.M.; Liu, S.; Hill-Skinner, S.; Wu, W.; Reed, D.; Yeh, C.-T.; Nettleton, D.; Schnable, P.S. The maize brown midrib2 (bm2) gene encodes a methylenetetrahydrofolate reductase that contributes to lignin accumulation. Plant J. 2014, 77, 380-392. [CrossRef]

82. Zhang, K.; Qian, Q.; Huang, Z.; Wang, Y.; Li, M.; Hong, L.; Zeng, D.; Gu, M.; Chu, C.; Cheng, Z. GOLD HULL AND INTERNODE2 encodes a primarily multifunctional cinnamyl-alcohol dehydrogenase in rice. Plant Physiol. 2006, 140, 972-983. [CrossRef] [PubMed]

83. D’Yvoire, M.B.; Bouchabke-Coussa, O.; Voorend, W.; Antelme, S.; Cezard, L.; Legee, F.; Lebris, P.; Legay, S.; Whitehead, C.; McQueen-Mason, S.J.; et al. Disrupting the cinnamyl alcohol dehydrogenase 1 gene (BdCAD1) leads to altered lignification and improved saccharification in Brachypodium distachyon. Plant J. 2013, 73, 496-508. [CrossRef]

84. Porter, K.; Axtell, J.; Lechtenberg, V.; Colenbrander, V. Phenotype, fiber composition, and in vitro dry matter disappearance of chemically induced brown midrib (bmr) mutants of sorghum. Crop Sci. 1978, 18, 205-208. [CrossRef] 
85. Barriere, Y.; Argillier, O.; Chabbert, B.; Tollier, M.T.; Monties, B. Breeding silage maize with brown-midrib genes-Feeding value and biochemical characteristics. Agronomie 1994, 14, 15-25. [CrossRef]

86. Cherney, J.; Cherney, D.; Akin, D.; Axtell, J. Potential of brown-midrib, low-lignin mutants for improving forage quality. In Advances in Agronomy; Sparks, D., Ed.; Elsevier: Amsterdam, The Netherlands, 1991; Volume 46, pp. 157-198.

87. Vermerris, W.; Saballos, A.; Ejeta, G.; Mosier, N.S.; Ladisch, M.R.; Carpita, N.C. Molecular breeding to enhance ethanol production from corn and sorghum stover. Crop Sci. 2007, 47, 142-153. [CrossRef]

88. Barnes, R.F.; Muller, L.D.; Bauman, L.F.; Colenbrander, V.F. In-vitro dry matter disappearance of brown midrib mutants of maize. J. Anim. Sci. 1971, 31, 881-884. [CrossRef]

89. Barriere, Y. Brown-midrib genes in maize and their efficiency in dairy cow feeding. Perspectives for breeding improved silage maize targeting gene modifications in the monolignol and $p$-hydroxycinnamate pathways. Maydica 2017, 62, 1-19.

90. Guillaumie, S.; Pichon, M.; Martinant, J.-P.; Bosio, M.; Goffner, D.; Barriere, Y. Differential expression of phenylpropanoid and related genes in brown-midrib $b m 1, b m 2, b m 3$, and $b m 4$ young near-isogenic maize plants. Planta 2007, 226, 235-250. [CrossRef]

91. Kuc, J.; Nelson, O.E. The abnormal lignins produced by the brown-midrib mutants of maize: I. The brown-midrib-1 mutant. Arch. Biochem. Biophys. 1964, 105, 103-113. [CrossRef]

92. Provan, G.J.; Scobbie, L.; Chesson, A. Characterisation of lignin from CAD and OMT deficient $b m$ mutants of maize. J. Sci. Food Agric. 1997, 73, 133-142. [CrossRef]

93. Santoro, N.; Cantu, S.L.; Tornqvist, C.-E.; Falbel, T.G.; Bolivar, J.L.; Patterson, S.E.; Pauly, M.; Walton, J.D. A high-throughput platform for screening milligram quantities of plant biomass for lignocellulose digestibility. Bioenergy Res. 2010, 3, 93-102. [CrossRef]

94. Barriere, Y.; Argillier, O. Brown-midrib genes of maize-A review. Agronomie 1993, 13, 865-876. [CrossRef]

95. Barriere, Y.; Emile, J.C.; Traineau, R.; Surault, F.; Briand, M.; Gallais, A. Genetic variation for organic matter and cell wall digestibility in silage maize. Lessons from a 34-year long experiment with sheep in digestibility crates. Maydica 2004, 49, 115-126.

96. Barriere, Y.; Guillet, C.; Goffner, D.; Pichon, M. Genetic variation and breeding strategies for improved cell wall digestibility in annual forage crops. A review. Anim. Res. 2003, 52, 193-228. [CrossRef]

97. Barriere, Y.; Mechin, V.; Riboulet, C.; Guillaumie, S.; Thomas, J.; Bosio, M.; Fabre, F.; Goffner, D.; Pichon, M.; Lapierre, C.; et al. Genetic and genomic approaches for improving biofuel production from maize. Euphytica 2009, 170, 183-202. [CrossRef]

98. Courtial, A.; Soler, M.; Chateigner-Boutin, A.-L.; Reymond, M.; Mechin, V.; Wang, H.; Grima-Pettenati, J.; Barriere, Y. Breeding grasses for capacity to biofuel production or silage feeding value: An updated list of genes involved in maize secondary cell wall biosynthesis and assembly. Maydica 2013, 58, 67-102.

99. Kiesselbach, T.A. Corn Investigations; University of Nebraska: Lincoln, NE, USA, 1922; Volume 20.

100. Eyster, W.H. Chromosome VIII in maize. Science 1926, 64, 22. [CrossRef] [PubMed]

101. Halpin, C.; Holt, K.; Chojecki, J.; Oliver, D.; Chabbert, B.; Monties, B.; Edwards, K.; Barakate, A.; Foxon, G.A. Brown-midrib maize (bm1)—A mutation affecting the cinnamyl alcohol dehydrogenase gene. Plant J. 1998, 14, 545-553. [CrossRef]

102. Barriere, Y.; Chavigneau, H.; Delaunay, S.; Courtial, A.; Bosio, M.; Lassagne, H.; Derory, J.; Lapierre, C.; Mechin, V.; Tatout, C. Different mutations in the ZmCAD2 gene underlie the maize brown-midrib1 (bm1) phenotype with similar effects on lignin characteristics and have potential interest for bioenergy production. Maydica 2013, 58, 6-20.

103. Burnham, C.; Brink, R. Linkage relations of a second brown midrib gene (bm2) in maize. Agron. J. 1932, $24,960-963$. [CrossRef]

104. Li, L.; Hill-Skinner, S.; Liu, S.; Beuchle, D.; Tang, H.M.; Yeh, C.-T.; Nettleton, D.; Schnable, P.S. The maize brown midrib4 (bm4) gene encodes a functional folylpolyglutamate synthase. Plant J. 2015, 81, 493-504. [CrossRef]

105. Green, A.R.; Lewis, K.M.; Barr, J.T.; Jones, J.P.; Lu, F.; Ralph, J.; Vermerris, W.; Sattler, S.E.; Kang, C. Determination of the structure and catalytic mechanism of Sorghum bicolor caffeic acid O-methyltransferase and the structural impact of three brown midrib12 mutations. Plant Physiol. 2014, 165, 1440-1456. [CrossRef]

106. Ye, Z.-H.; Kneusel, R.E.; Matern, U.; Varner, J.E. An alternative methylation pathway in lignin biosynthesis in Zinnia. Plant Cell 1994, 6, 1427-1439. [CrossRef] 
107. Wu, Z.; Ren, H.; Xiong, W.; Roje, S.; Liu, Y.; Su, K.; Fu, C. Methylenetetrahydrofolate reductase modulates methyl metabolism and lignin monomer methylation in maize. J. Exp. Bot. 2018, 69, 3963-3973. [CrossRef]

108. Vignols, F.; Rigau, J.; Torres, M.A.; Capellades, M.; Puigdomenech, P. The brown midrib3 (bm3) mutation in maize ocurs in the gene encoding caffeic acid O-methyl transferase. Plant Cell 1995, 7, 407-416. [CrossRef] [PubMed]

109. Morrow, S.L.; Mascia, P.; Self, K.A.; Altschuler, M. Molecular characterization of a brown midrib3 deletion mutation in maize. Mol. Breed. 1997, 3, 351-357. [CrossRef]

110. Burnham, C.R. Cytogenetic studies of a translocation between chromosome-1 and chromosome-7 in maize. Genetics 1948, 33, 5-21.

111. Vermerris, W.; Sherman, D.M.; McIntyre, L.M. Phenotypic plasticity in cell walls of maize brown midrib mutants is limited by lignin composition. J. Exp. Bot. 2010, 61, 2479-2490. [CrossRef]

112. Ali, F.; Scott, P.; Bakht, J.; Chen, Y.; Luebberstedt, T. Identification of novel brown midrib genes in maize by tests of allelism. Plant Breed. 2010, 129, 724-726. [CrossRef]

113. Mechin, V.; Laluc, A.; Legee, F.; Cezard, L.; Denoue, D.; Barriere, Y.; Lapierre, C. Impact of the brown-midrib bm5 mutation on maize lignins. J. Agric. Food Chem. 2014, 62, 5102-5107. [CrossRef]

114. Ralph, J.; Kim, H.; Lu, F.; Grabber, J.H.; Leplé, J.C.; Berrio-Sierra, J.; Derikvand, M.M.; Jouanin, L.; Boerjan, W.; Lapierre, C. Identification of the structure and origin of a thioacidolysis marker compound for ferulic acid incorporation into angiosperm lignins (and an indicator for cinnamoyl CoA reductase deficiency). Plant J. 2008, 53, 368-379. [CrossRef]

115. Chen, Y.; Liu, H.; Ali, F.; Scott, M.P.; Ji, Q.; Frei, U.K.; Luebberstedt, T. Genetic and physical fine mapping of the novel brown midrib gene bm6 in maize (Zea mays L.) to a $180 \mathrm{~kb}$ region on chromosome 2. Theor. Appl. Genet. 2012, 125, 1223-1235. [CrossRef]

116. Stephens, J.; Halpin, C. Barley 'Orange Lemma' is a Mutant in the CAD Gene. Unpublished poster. 2008.

117. Meyer, D.W.; Franckowiak, J.D.; Nudell, R.D. Forage quality of barley hay. In Agronomy Abstracts; ASA: Madison, WI, USA, 1994.

118. Daly, P.; Stephens, J.; Halpin, C. Barley 'Orange Lemma'-A Mutant in Lignin Biosynthesis? unpublished poster. 2007.

119. Newton, A.C.; Flavell, A.J.; George, T.S.; Leat, P.; Mullholland, B.; Ramsay, L.; Revoredo-Giha, C.; Russell, J.; Steffenson, B.J.; Swanston, J.S. Crops that feed the world 4. Barley: A resilient crop? Strengths and weaknesses in the context of food security. Food Secur. 2011, 3, 141-178. [CrossRef]

120. Myler, J.L.; Stanford, E.H. Color inheritance in barley. Agron. J. 1942, 34, 427-436. [CrossRef]

121. Falk, D.E. Linkage data with genes near the centromere of barley chromosome 6. Barley Genet. Newsl. 1980, 10, 13-16.

122. Kutcher, H.R.; Bailey, K.L.; Rossnagel, B.G.; Franckowiak, J.D. Linked morphological and molecular markers associated with common root rot reaction in barley. Can. J. Plant Sci. 1996, 76, 879-883. [CrossRef]

123. Falk, D.E. Presowing selection of male sterile barley plants for the production of outcrossed seeds. Barley Genet. Newsl. 1984, 14, 25-27.

124. Falk, D.E. Creation of a marked telo 6S trisomic for chromosome 6. Barley Genet. Newsl. 1994, $23,33-35$.

125. Zeng, D.-L.; Qian, Q.; Dong, G.-J.; Zhu, X.-D.; Dong, F.-G.; Teng, S.; Guo, L.-B.; Cao, L3.-Y.; Cheng, S.-H.; Xiong, Z.-M. Development of isogenic lines of morphological markers in indica rice. Acta Bot. Sin. 2003, 45, 1116-1120.

126. Hirano, K.; Masuda, R.; Takase, W.; Morinaka, Y.; Kawamura, M.; Takeuchi, Y.; Takagi, H.; Yaegashi, H.; Natsume, S.; Terauchi, R.; et al. Screening of rice mutants with improved saccharification efficiency results in the identification of CONSTITUTIVE PHOTOMORPHOGENIC 1 and GOLD HULL AND INTERNODE 1. Planta 2017, 246, 61-74. [CrossRef]

127. Hong, L.; Qian, Q.; Tang, D.; Wang, K.; Li, M.; Cheng, Z. A mutation in the rice chalcone isomerase gene causes the golden hull and internode 1 phenotype. Planta 2012, 236, 141-151. [CrossRef] [PubMed]

128. IRRI, A.C. Global Rice Science Partnership (GRiSP); Council for Partnership on Rice Research in Asia: Metro Manila, Philippines, 2010.

129. Park, J.-y.; Kanda, E.; Fukushima, A.; Motobayashi, K.; Nagata, K.; Kondo, M.; Ohshita, Y.; Morita, S.; Tokuyasu, K. Contents of various sources of glucose and fructose in rice straw, a potential feedstock for ethanol production in Japan. Biomass Bioenergy 2011, 35, 3733-3735. [CrossRef] 
130. Mouradov, A.; Spangenberg, G. Flavonoids: A metabolic network mediating plants adaptation to their real estate. Front. Plant Sci. 2014, 5, 620. [CrossRef]

131. Sattler, S.E.; Saballos, A.; Xin, Z.; Funnell-Harris, D.L.; Vermerris, W.; Pedersen, J.F. Characterization of novel sorghum brown midrib mutants from an EMS-mutagenized population. G3 2014, 4, 2115-2124. [CrossRef]

132. Saballos, A.; Vermerris, W.; Rivera, L.; Ejeta, G. Allelic association, chemical characterization and saccharification properties of brown midrib mutants of sorghum (Sorghum bicolor (L.) Moench). Bioenergy Res. 2008, 1, 193-204. [CrossRef]

133. Vogler, R.; Ejeta, G.; Johnson, K.; Axtell, J. Characterization of a new brown midrib sorghum line. In Agronomy Abstracts; ASA: Madison, WI, USA, 1994; p. 124.

134. Gupta, S.C. Allelic relationships and inheritance of brown midrib trait in sorghum. J. Hered. 1995, 86, 72-74. [CrossRef]

135. Xin, Z.; Wang, M.L.; Barkley, N.A.; Burow, G.; Franks, C.; Pederson, G.; Burke, J. Applying genotyping (TILLING) and phenotyping analyses to elucidate gene function in a chemically induced sorghum mutant population. BMC Plant Biol. 2008, 8, 103. [CrossRef]

136. Xin, Z.; Wang, M.L.; Burow, G.; Burke, J. An induced sorghum mutant population suitable for bioenergy research. Bioenergy Res. 2009, 2, 10-16. [CrossRef]

137. Bittinger, T.; Cantrell, R.; Axtell, J. Allelism tests of the brown-midrib mutants of sorghum. J. Hered. 1981, 72, $147-148$. [CrossRef]

138. Li, X.; Weng, J.K.; Chapple, C. Improvement of biomass through lignin modification. Plant J. 2008, 54, 569-581. [CrossRef] [PubMed]

139. Da Silva, M.J.; Souza Carneiro, P.C.; de Souza Carneiro, J.E.; Borges Damasceno, C.M.; Lacerda Duraes Parrella, N.N.; Pastina, M.M.; Ferreira Simeone, M.L.; Schaffert, R.E.; da Costa Parrella, R.A. Evaluation of the potential of lines and hybrids of biomass sorghum. Ind. Crops Prod. 2018, 125, 379-385. [CrossRef]

140. Saballos, A.; Sattler, S.E.; Sanchez, E.; Foster, T.P.; Xin, Z.; Kang, C.; Pedersen, J.F.; Vermerris, W. Brown midrib2 (Bmr2) encodes the major 4-coumarate: Coenzyme A ligase involved in lignin biosynthesis in sorghum (Sorghum bicolor (L.) Moench). Plant J. 2012, 70, 818-830. [CrossRef]

141. Saballos, A.; Ejeta, G.; Sanchez, E.; Kang, C.; Vermerris, W. A genomewide analysis of the cinnamyl alcohol dehydrogenase family in sorghum [Sorghum bicolor (L.) Moench] identifies SbCAD2 as the brown midrib6 gene. Genetics 2009, 181, 783-795. [CrossRef] [PubMed]

142. Sattler, S.E.; Saathoff, A.J.; Haas, E.J.; Palmer, N.A.; Funnell-Harris, D.L.; Sarath, G.; Pedersen, J.F. A nonsense mutation in a cinnamyl alcohol dehydrogenase gene is responsible for the sorghum brown midrib6 phenotype. Plant Physiol. 2009, 150, 584-595. [CrossRef]

143. Scully, E.D.; Gries, T.; Funnell-Harris, D.L.; Xin, Z.; Kovacs, F.A.; Vermerris, W.; Sattler, S.E. Characterization of novel Brown midrib 6 mutations affecting lignin biosynthesis in sorghum. J. Integr. Plant Biol. 2016, 58, 136-149. [CrossRef]

144. Pillonel, C.; Mulder, M.M.; Boon, J.J.; Forster, B.; Binder, A. Involvement of cinnamyl-alcohol dehydrogenase in the control of lignin formation in Sorghum bicolor L. Moench. Planta 1991, 185, 538-544. [CrossRef] [PubMed]

145. Bucholtz, D.L.; Cantrell, R.P.; Axtell, J.D.; Lechtenberg, V.L. Lignin biochemistry of normal and brown midrib mutant sorghum. J. Agric. Food Chem. 1980, 28, 1239-1241. [CrossRef]

146. Godin, B.; Nagle, N.; Sattler, S.; Agneessens, R.; Delcarte, J.; Wolfrum, E. Improved sugar yields from biomass sorghum feedstocks: Comparing low-lignin mutants and pretreatment chemistries. Biotechnol. Biofuels 2016, 9, 251. [CrossRef] [PubMed]

147. Oliver, A.L.; Pedersen, J.F.; Grant, R.J.; Klopfenstein, T.J. Comparative effects of the sorghum $b m r-6$ and bmr-12 genes: I. Forage sorghum yield and quality. Crop Sci. 2005, 45, 2234-2239. [CrossRef]

148. Oliver, A.L.; Pedersen, J.F.; Grant, R.J.; Klopfenstein, T.J.; Jose, H.D. Comparative effects of the sorghum $b m r-6$ and $b m r-12$ genes: II. Grain yield, stover yield, and stover quality in grain sorghum. Crop Sci. 2005, 45, 2240-2245. [CrossRef]

149. Oliver, A.L.; Grant, R.J.; Pedersen, J.F.; O’Rear, J. Comparison of brown midrib-6 and-18 forage sorghum with conventional sorghum and corn silage in diets of lactating dairy cows. J. Dairy Sci. 2004, 87, 637-644. [CrossRef]

150. Bout, S.; Vermerris, W. A candidate-gene approach to clone the sorghum brown midrib gene encoding caffeic acid O-methyltransferase. Mol. Genet. Genom. 2003, 269, 205-214. [CrossRef] 
151. Sattler, S.E.; Palmer, N.A.; Saballos, A.; Greene, A.M.; Xin, Z.; Sarath, G.; Vermerris, W.; Pedersen, J.F. Identification and characterization of four missense mutations in brown midrib 12 (bmr12), the caffeic O-methyltranferase (COMT) of sorghum. Bioenergy Res. 2012, 5, 855-865. [CrossRef]

152. Funnell-Harris, D.L.; O'Neill, P.M.; Sattler, S.E.; Gries, T.; Berhow, M.A.; Pedersen, J.F. Response of sorghum stalk pathogens to brown midrib plants and soluble phenolic extracts from near isogenic lines. Eur. J. Plant Pathol. 2017, 148, 941-953. [CrossRef]

153. Catalan, P.; Chalhoub, B.; Chochois, V.; Garvin, D.F.; Hasterok, R.; Manzaneda, A.J.; Mur, L.A.; Pecchioni, N.; Rasmussen, S.K.; Vogel, J.P. Update on the genomics and basic biology of Brachypodium: International Brachypodium Initiative (IBI). Trends Plant Sci. 2014, 19, 414-418. [CrossRef] [PubMed]

(C) 2019 by the authors. Licensee MDPI, Basel, Switzerland. This article is an open access article distributed under the terms and conditions of the Creative Commons Attribution (CC BY) license (http://creativecommons.org/licenses/by/4.0/). 